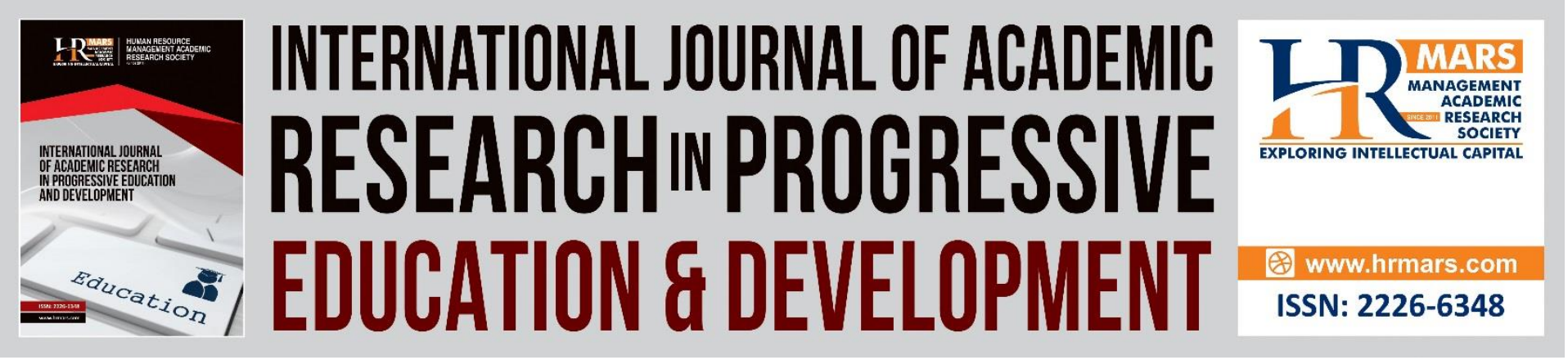

\title{
Effects of Orphan hood on Girl-child's Access and Retention in Secondary School Education: A Case of Rongo District, Kenya
}

Ombuya, Benjamin Dickens, Yambo, John M. Onyango, Omolo Tom Mboya

To Link this Article: http://dx.doi.org/10.6007/IJARPED/v1-i4/12009 DOI: 10.6007/IJARPED/v1-i4/12009

Received: 19 September 2012, Revised: 20 October 2012, Accepted: 30 October 2012

Published Online: 19 November 2012

In-Text Citation: (Ombuya et al., 2012)

To Cite this Article: Ombuya, B. D., Yambo, J. M. O., \& Mboya, O. T. (2012). Effects of Orphan hood on Girlchild's Access and Retention in Secondary School Education: A Case of Rongo District, Kenya. International Journal of Academic Research in Progressive Education and Development, 1(4), 149-168.

Copyright: (c) 2012 The Author(s)

Published by Human Resource Management Academic Research Society (www.hrmars.com)

This article is published under the Creative Commons Attribution (CC BY 4.0) license. Anyone may reproduce, distribute, translate and create derivative works of this article (for both commercial and non-commercial purposes), subject to full attribution to the original publication and authors. The full terms of this license may be seen at: http://creativecommons.org/licences/by/4.0/legalcode

Vol. 1(4) 2012, Pg. 149 - 168

Full Terms \& Conditions of access and use can be found at http://hrmars.com/index.php/pages/detail/publication-ethics 


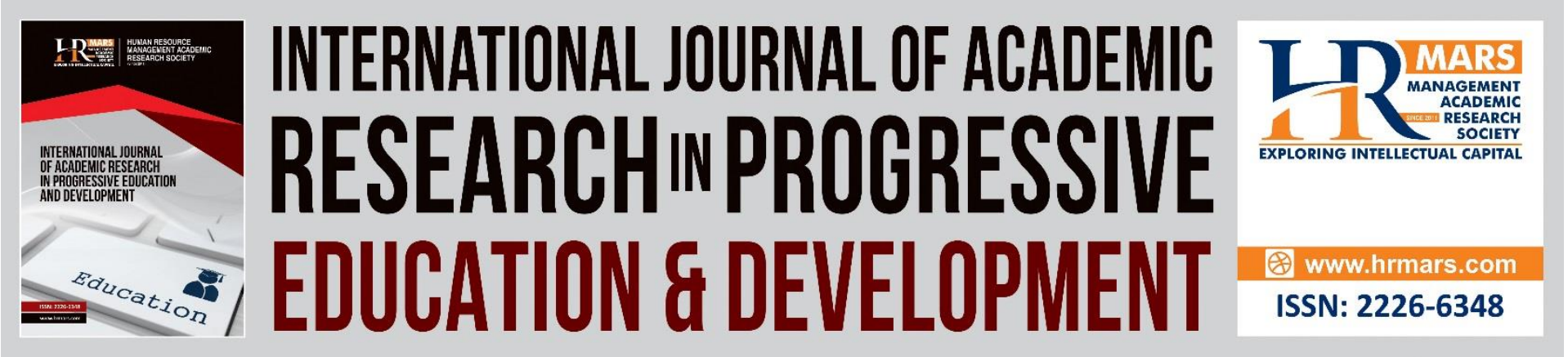

\title{
Effects of Orphan hood on Girl-child's Access and Retention in Secondary School Education: A Case of Rongo District, Kenya
}

\author{
Ombuya, Benjamin Dickens \\ Department of Psychology, Maseno University, Homa-Bay Campus, Kenya \\ Email: dombuyamin@yahoo.com
}

Yambo, John M. Onyango

Department of Educational Management, University of Eastern Africa-Baraton (Kamagambo

Adventist College Campus, Kenya)

Omolo Tom Mboya

Department of Psychology, Moi University, Rongo University College, Kenya

\begin{abstract}
This study focused on orphan hood which is a critical issue in almost every household not only in Kenya but also the world over. Orphans are at risk of losing their learning time as well as being involved in child labor among others. Orphan hood can be associated with an increased demand of the child's time in home production which results in less schooling. The objective of this article was; to identify the school related effects of orphan hood on the girl-child's access and retention in secondary school education in Rongo District, Kenya. Ho 1 : There is no statistically significant school related effects of orphan hood on the girl-child's access and retention in secondary school education in Rongo District, Kenya. This study was guided by the classical -liberal theory of equal opportunity (Rousseau, 1712) asserted that each person is born with a given amount of capacity, which to a large extent is inherited and cannot be substantially changed. The study adopted the descriptive survey design and targeted a population of orphaned girl-child in secondary schools in Rongo District, Kenya.36 Head teachers and 36 teacher counselors from the 36 sampled secondary schools in Rongo District were included in the study to provide the required information about the orphaned girl-child. The 36 sampled secondary schools included 23 mixed day, 5 girls boarding, 6 mixed day/boarding and 2 mixed boarding secondary schools. Simple random sampling was used to select 468 orphaned girls, and purposive random sampling was used to include the 36 head teachers and 36 teacher counselors totaling to 540 respondents. Data was collected using closed and open ended questionnaires. The questionnaires were pre-tested by being administered to 30 respondents from two schools which were not included in the study. The scores obtained from the first and second tests were 0.76 and 0.77 respectively. The descriptive statistics including percentages mean and frequency tables were used to analyze
\end{abstract}


the data. Inferential statistics such as chi-square $\left(\chi^{2}\right)$ was also used to analyze quantitative data. All hypotheses testing procedures were based on $\alpha=0.05$ level of significance. Data was analyzed using the Statistical Package for Social Sciences (SPSS) version 11.0 computer programme. The study found out that orphan hood significantly affects the girl-child's access and retention in secondary school education in Rongo District. The study recommends that guidance and counseling interventions be put in place to address school related, sociocultural, socio-economic effects and needs of orphaned girl-child. The results of the study would help the government in formulation of policy and programme interventions aimed at helping the orphaned girl-child and to specifically address the needs of the families with such children by making the said policies and programmes as proactive as possible to the needs of the orphans.

Keywords: Kenya, Orphan Hood, Girl-child, Access, Retention, Secondary School, Education

\section{Introduction}

Orphan hood being a condition whereby a child loses one or both parents through death is a critical issue in every household in the world over and raises concern to every individual in the society. It is estimated that twenty four of twenty- five countries with the world's highest levels of HIV/AIDS prevalence rates are in Sub-Saharan Africa as reflected in the current number of orphaned children (USAID, 2003). According to a joint report by UNAIDS, UNICEF and USAID (2004), at least $12.3 \%$ of all children in Sub-Saharan Africa or 43 million children are orphans (who have lost one or both parents). Moreover, although the numbers of orphans in other regions of the world are decreasing, the numbers in Sub-Saharan Africa are increasing, mainly because sub-Saharan Africa, as a region, has been hit hardest by HIV/AIDS (UNAIDS et al., 2004). Traditionally, the burden of rising up orphans in the Sub-Saharan Africa falls primarily to the surviving extended family members comprising grandparents, uncles, aunts and friends.

Unfortunately, the steady increase in the number of orphans, especially in the last two decades, coupled with the increase in poverty in the region, has overwhelmed the traditional extended family system (Ssewamala, 2005). As a result, a considerable number of orphaned girl-children who would otherwise have been cared for within the extended family system have dropped out of school in order to either farm the family land to take care of themselves and their siblings, or in desperation, migrated to large urban areas in search of employment opportunities (child labor), or forced into marriage (Orodho, 2004). In Kenya, orphan hood has consistently affected education of very many children and the girl-child in particular. UNICEF (2004) estimated that Kenya had about 1,659,000 orphans (or $12 \%$ of the children) out of who about $54 \%$ were orphaned through HIV/AIDS. Other causes may include armed conflicts, accidents and deaths from other diseases /sicknesses.

Rongo District, Kenya, is dominantly inhabited by the Luo community and it is bordered by the Abagusii community. Considering recent past political events the area might be prone to armed fighting occurring between the two named communities and this also may be the cause of orphan hood to many children in the district.

\section{Statement of the Problem}

The family being the cradle of a child's development provides the child with emotional and educational support. However, increase in the rate of orphan hood is steadily overwhelming 
the extended family systems which have been known to take up the burdens of orphans. This has created an upsurge of a number of child headed families, and in specific terms the girlchild headed families which are experiencing starvation, poor health and lack of education. Without adequate support the orphaned girl-child stands a risk of prostitution, child labor, child abuse, HIV/AIDS among others. Furthermore, this poses a risk to the orphaned girl-child not accessing and continuing with secondary school education. The study therefore was to determine the effects of orphan hood on the girl-child's access and retention in secondary school education in Rongo District, Kenya.

\section{The Concept of Orphan hood}

Orphan hood refers to a state whereby a child has her parent(s) dead and left either alone to fend for her life, or depend on a relative, friend or care givers/ care takers (Beegle, 2006). In Sub-Sahara Africa, the prevalence of orphan hood among children has been greatly made worse by the HIV/AIDS pandemic (Weerdt, 2006). Therefore, orphan hood is expected to influence health outcomes and schooling. It has been noted further that orphan hood can be associated with an increased value of the child's time in home production (as a substitute for adult labor) which results in less schooling.

An orphan cared for by a relative may experience more different treatments than she could have got had her parents been alive. There may be discrimination against orphans and favoritisms shown towards biological children for double or among single orphans who reside at foster parents' home. Many previous researchers have noted that beyond financial constrains of adult deaths and implications of a loss of parental involvement, children who become orphans may suffer trauma which, in turn, affect their academic achievements and retention in school. They may also be stigmatized and this may affect them negatively in achieving their Education (Crampin, 2003; Floyd, 2003; Yambo et al, 2012; Glynn, 2005; Madise, 2003; Nyondo; 2003; Khondwe, 2003). Ainsworth and Filmer (2006) argue that considerable diversity in the orphan/ non-orphan differential across countries makes it difficult to draw generalization about the extent to which orphans are educationally disadvantaged. The same argument was advanced by Case, Paxon, and Ableidinger (2004) using household fixed assets found that orphans are educationally disadvantaged relatively to other children within the same household. Moreover, this is not true with orphans who have well established assets left behind by the parents (Hill \& Sandfort, 1995). Such orphans are likely to be enrolled in schools without delay, retained in schools and achieve their academic goals.

\section{Girl -Child Education}

The girl-child education is one of the most serious important issues being emphasized by the developing governments of the world (UNICEF, 2001). However, certain factors encroach in and impede the educational progress of girls in the society. Such factors include; early marriage, pre-marital sex leading to pregnancy, socio-cultural factors, socio-economic factors, geographical factors among others. These factors as postulated by Levy (1993) inadvertently affect the incentives to educate girls. It has also been realized that adolescent pregnancy almost always results in the discontinuation of girls' access and continuity to secondary school education (Kodzamira \& Chiswana, 2000). Many of such girls end up in marriage or abandoned at home without any academic achievement realized. According to Tawanda and Gordon (2004), there are other major out of school factors that hinder the 
orphaned girl child from accessing secondary school education. These factors also affect the academic achievement and retention of such girls in secondary schools. These factors include loss of parents through death and divorce, inability of many parents to raise school fees, lack of money for uniforms, books, pens and other costs associated with school, beating and abuse of the orphaned girl- child by step parents/guardians, pregnancy and drug abuse. There are also school factors such as insults from teachers, excessive corporal punishment by teachers, bullying by other pupils especially boys, lack of proper school equipment and thefts. Together with the factors mentioned above, other factors such as gender bias, poverty, orphan hood, political or administrative bias, religious factors, educational factors and lack of initiatives that are not detrimental to girl-child's access and retention in secondary school education still need to be addressed through affirmative action and the government policies and programmes put in place to enable the orphaned girl-child in particular to access and be retained in secondary school education.

School Related Effects of Orphan hood

Hargreaves and Glynn (2002) postulate that the consequences of orphan hood focus greatly on the educational achievements of a child orphaned. They further argue that orphan hood creates a state of hopelessness among students who are orphaned, especially when they realize that little quality would be realized in their educational endeavors. Similarly, Case, Paxon and Ableidinger (2004) indicated that orphaned children in sub-Saharan Africa are less likely to be enrolled in schools than are non-orphaned with whom they live. They further conclude that academic achievements for orphans depend on the relationship of the orphans to their household heads. This argument indicates that the lower enrolment of orphans in schools is largely explained by the greater tendency of orphans to live with distant relatives or unrelated caregivers. Therefore, it is very important to determine an orphan's schooling by considering where an orphan is taken care.

Castle (1996) noted that apart from academics and enrolment, other out of class issues edge girls out of school. These issues include sexual abuse and rape. Orphaned girls are subjected to sexual abuse by male teachers and male students due to their vulnerability. This affects their morale to schooling; thus interfering with their concentration and performance. Female teachers also show dislike for girls because of the girls' looks, hairstyles and so on.

UNICEF (2004) identified difficulties girls face in accessing and being retained in schools in rural areas. These difficulties include harassment by boys, long distances to be covered between school and home, early pregnancy, lack of resources and lack of female teachers in secondary schools in the rural areas to act as role models to girls. This is because the facilities for accommodation and security of such teachers are usually absent or inadequate. However, on certain issues such as early pregnancies things have since changed and pregnant girls are allowed maternity leave and then allowed back to continue with school. Despite this opportunity given to such girls, many of them still drop out of school due to domestic problems and stigma.

Beegle (2006) postulates that orphaned children whose parents died of HIV/AIDS are stigmatized and suffer trauma in schools due to lack of confidentiality and privacy in handling them. Perhaps this is possible only in schools where there are no trained teacher-counselors to handle orphaned children, especially the girl-child. It has also been noted that training of 
such teachers is not regularly held and if done, then it reaches very few teachers at a given time. In most cases, only the head teachers who benefit from many of such train opportunities. Case, Paxon and Ableidinger, (2004) postulate that at the time of parental death, the enrolment of an orphaned child is affected by the impact of orphan hood. While they further note that delayed entry into secondary schools by such orphans to some extent reflects wealth effects (since richer children are more likely to be enrolled in schools without delay), Deininger, Meier and UNICEF (2003) argue that timely secondary schools' entry of such orphans depend on household attitudes towards education or the social pressure from the community of the host family not to deprive the orphan in any obvious way. Otherwise, delayed entry of such orphans into secondary schools may result into higher dropout rate as well as lower probability of continuation in secondary schools. Indeed, it would be assumed that double-orphaned children being taken in by the economically stable households are not being given the opportunity to enroll in secondary schools because they are being used as helpers or maids in the households where they live.

The Government policies and programmes on education target all children regardless of orphan hood status and economic stability of the household in which they live (GOK, 2001). Furthermore, it is noted that the Kenya Government has introduced Free Primary Education (F.P.E). This has shown that primary school enrolment among orphans has increased from $60 \%$ to $88 \%$ (UNICEF, 2004). The same policy applies in secondary schools to help the orphans, especially the girl-child, with education, though the bursary allocation in secondary schools is still playing an insignificant role. Otherwise, the girl-child needs to benefit from this free secondary school education a great deal. Socio-Cultural Effects of Orphan hood

The prevalence of orphan hood among the children in sub-Saharan Africa has been greatly exacerbated by the HIV/AIDS pandemic (Beegle, 2003). This shows that HIV/AIDS pandemic has major effects on the mortality of men and women in their prime child bearing and earning years. Consequently, orphan hood rates are increasing and putting a larger share of children at risk. According to Orodho (2004), many of such orphans have subsequently dropped out of school in order to either farm the family land to take care of themselves and their siblings, or in desperation migrated to large urban centers in search of employment opportunities, or forced into marriage.

Attitudes do play a major role in provision of educational opportunities. However, a major deterrent to female take up and follow through educational opportunities is near universal fundamental cultural bias in favor of males. The research carried out in sub-Saharan Africa found out that the widespread operation of patriarchal systems of social organizations on early pregnancy, on heavier domestic and subsistence duties of females (especially in rural areas) and a generally lower regard for the value of female life, adversely affect the participation of girls and women in formal education (USAID, 2004).

Poverty and malnutrition are other factors deterrent to secondary school education attainment of orphaned girl-child. Lindblade, Odhiambo, Rosen, and Decocks (2003) emphasize that the effect of poverty and malnutrition on the health of school age orphan falls harder on girls than boys. Boys may get preferential feeding, while girls (who have heavier workload) are more likely to be undernourished. This adversely affects their enrolment, academic achievement and retention rate in schools. 
Cultural factors also play a major role in deterring orphaned girl child's access and academic achievement in secondary school education. Silver (1973) postulates that culture overburdens girls with more responsibilities than boys. He noted that in a case whereby a mother dies, a girl may be brought home to take care of the family and other siblings at the expense of schooling whilst the boys are allowed to continue with schooling. In addition, girls suffer from traditions such as early/post marriages in exchange for bride price transforming the school girls into a commodity for exchange auctioned to the highest bidder so that their brothers can continue with education (Rono, 1990). It has been noted that the situation is made worse when the parents have died and girls remain under a care-giver. In rural areas, it is not uncommon for poor families to endorse early marriage for girls to lighten the family's economic burdens, and becomes a reason for such girls to leave school prematurely.

The high cost of schooling and the inability of poor orphaned girls to buy uniforms and acquire other basic necessities may encourage the girls to seek sexual relationship with older men who can provide them with money to use. The effect of this relationship results into pregnancy of such girls who are then expelled from schools, thus cutting short their schools careers (FAWE, 1994). Even though such girls are encouraged to return to school after delivery of the baby, it becomes a difficult task for an orphaned girl because there would be nobody to remain at home with the child born, or their care-givers fear that they would become pregnant again, or the girls themselves fear of being ridiculed or feel stigmatized (Corcoran, 1995).

\section{Methodology}

The study used a descriptive survey design to collect data through questionnaires from the study sample. The descriptive survey design attempted to collect data from the sample of the study in order to determine the effect of orphan hood on the girl-child's access and retention in secondary school education in Rongo District, Kenya. The choice of the design was made because the nature of data needed for the study did not involve or required time series over several monitoring rounds of data. It involved collection of information from a sample that had been drawn from a predetermined population at one point in time (Fraenkel \& Wallen, 2000). Furthermore, Borg and Gall (1989) note that descriptive survey research is intended to produce statistical information about aspects of education that interests policy makers and educators. Therefore, the descriptive survey that was employed explored opinions, attitudes and knowledge about the effect of orphan hood on the girl-child's access and retention in secondary school education in the area of study. These schools included mixed day, girls' boarding, mixed day/boarding and mixed boarding secondary schools. The study excluded boys day/and, or boarding secondary schools. Rongo district, in Nyanza Province, borders Homa-Bay district to the North, Migori district to the South, Ndhiwa district to the West and South Gucha district to the East. The district has three educational divisions namely Rongo division, Uriri division and Awendo division, with a total of 56 secondary schools and approximate student population of 15,354. Most of the schools are mixed secondary schools, and there are only five girls' boarding secondary schools in the district. The target population of the study consisted of the orphaned girl-child in secondary schools in Rongo District, Kenya. However, the head teachers and teacher counselors in the area of study were also targeted to provide the required information about the effect of orphan hood on the girl child's access and retention in secondary school education in Rongo district, Kenya. There were 56 (fifty six) secondary schools in the district with approximate population of about 15,354 students 
categorized as 36 mixed day secondary schools, 5 girls boarding secondary schools, 4 mixed day/ boarding, 9 boys boarding secondary schools, and 2 mixed boarding secondary schools (Cited from DEO Rongo, 2008). The study excluded the 9 boys boarding secondary schools and used 47 secondary schools with girl- child population. The table below indicated the population of girl-child in secondary schools in the district where the sample size was drawn.

Table 1:

Enrolment of girl-child in secondary schools in Rongo District, 2009

\begin{tabular}{llll}
\hline \hline Enrolment & Double Orphans & Single Orphans & Total \\
5735 & 459 & 1032 & 1491
\end{tabular}

Source: DEO's office Rongo, 2009: Enrolment statistics.

In this study, three groups of respondents namely; head teacher teacher-counsellors and orphaned girl-child were used to provide the required information about the effect of orphan hood on the girl-child's access and retention in secondary school education in Rongo district, Kenya. The sample frame was 47 secondary schools with the girl-child population, out of which 36 sampled secondary schools were randomly selected. From each of the selected 36 secondary schools, one head teacher and one teacher counsellor (yielding to 36 head teachers and 36 teacher counselors) were included in the study to provide the required information. Simple random sampling was used to target 13 orphaned girl-children from each school yielding to a total of 468 orphaned girl-children from the 36 secondary schools. The sample size of schools from each division was proportionally selected as indicated in table 2 below. The entire sampling matrix yielded a total sample size of 540 respondents for the study. Since there were only five girls' boarding secondary schools in Rongo District, Kenya, they were all automatically selected. This sample of orphaned girl-child from the target population was chosen because according to Mugenda and Mugenda (1999) the population of study was found to be homogeneous in characteristics (orphaned girl-child in secondary schools). For descriptive survey, the minimum recommended sample size is 20-50 in each minor sub-group (Borg \& Gall, 2003). In this study, the minor sub-group comprised a total of 36 subjects in each sub- group, which was within the minimum to cater for attrition. The proposed sample size in the study was 540 respondents. According to Mugenda and Mugenda (1999), the following formula might be used to determine the sample size:

$$
\mathrm{n}=\frac{\mathrm{z}^{2} \mathrm{pq}}{\mathrm{d}^{2}}
$$

Whereby: $n=$ desired sample size (if targeted population is greater than 10,000 ).

$Z$ = standard normal deviate at required confidence level.

$\mathrm{P}=$ proportion in the target population estimated to have characteristics being measured.

$q=1-p$

$d=$ level of statistical significance set. 
DEVELOPMENT

Vol. 1, No. 4, 2012, E-ISSN: 2226-6348 @ 2012 HRMARS

Table 2:

Sample size by the schools per division

\begin{tabular}{lllllll}
\hline Divisios & Schools & $\begin{array}{l}\text { Schools } \\
\text { sampled }\end{array}$ & Sample Size & & \\
\hline & & & H/teache & T/counselor & & Total \\
Rongo & 18 & 14 & r & S & Students & \\
Awendo & 17 & 13 & 13 & 14 & 182 & 207 \\
Uriri & 12 & 9 & 9 & 13 & 169 & 195 \\
Total & 47 & 36 & 36 & 36 & 117 & 138 \\
& & & & & 468 & 540
\end{tabular}

According to Ballian (1998) in case there is a need to adjust upward or downward the sample size then it can be calculated at $10-15 \%$ in order to cater for attrition. Therefore the sample size for this study was calculated at 13 orphaned girl-children per school totaling to a sample size of 468 orphaned girl-children from the 36 sampled secondary schools in the district. Simple random sampling was used to select the orphaned girl-children for the study.

Data collection instruments included structured questionnaires for head-teachers, teacher counselors and orphaned girl-child. The questionnaires were considered ideal for collecting data from the head teachers, teacher counselors and orphaned girl-child in secondary schools because these respondents could interpret and record the questionnaires on their own. In the structured questionnaires, the question items helped the researcher to get information from the respondents. Each questionnaire type had three sections (A, B, C). Section background information of the respondents, Sections $B$ and $C$ - home and school related effects of orphan hood on the girl-child access and retention in secondary school education respectively. After data collection, the responses to the questionnaire were coded, and then data was entered into the computer for analysis. Data was entered according to respondents' identification number based on the schools. The data which largely came from individual respondents was analyzed using both descriptive and inferential statistics. Frequencies and percentages were used for descriptive statistics, while chi- square $\left(\chi^{2}\right)$ was used to analyze quantitative data. All the hypothesis testing procedures were based on $\alpha=0.05$ level of significance test of independence used to test the effects of orphan hood on the girl-child's access and retention in secondary school education. The Statistical Package for Social Sciences (SPSS) version 11.5 was the computer programme used for the analysis of the data.

\section{Results and Discussions}

The School Related Effects of Orphan hood on the Girl - Child's Access and Retention in Secondary School Education in Rongo District.

This objective aimed at identifying the school related effects of orphan hood that hinder the girl-child's access and retention in secondary school education in Rongo District. These effects included the category of schools, number and category of teachers in guidance counseling department, poor academic performance, distance orphaned girls covers from home to closest day secondary school and other causes of orphaned girl's dropout from school. It is 
DEVELOPMENT

Vol. 1 , No. 4, 2012, E-ISSN: $2226-6348$ @ 2012 HRMARS

concluded by testing hypothesis on effect of frequent visit to guidance and counseling department and forced repetition of a class by orphaned girl- child.

Category of Schools Orphaned Girl- Child Attended and their Effects on Access and Retention in Secondary School Education

The category and current type of schools orphaned girl- child attended was considered in the study because secondary schools have varied administrative techniques and environment that positively or negatively affect students' access and retention in schools.

Table 2

Effects of School Category Orphaned Girl - Child Attended and its influence on access and retention on secondary school education

\begin{tabular}{lcr}
\hline School Category & Frequency & Percent \\
\hline Mixed day & 26 & 72.2 \\
Mixed day/ boarding & 3 & 8.3 \\
Girls boarding & 6 & 16.7 \\
Mixed boarding & 1 & 2.8 \\
Total & $\mathbf{3 6}$ & $\mathbf{1 0 0 . 0}$ \\
\hline
\end{tabular}

$\mathrm{N}=36$

The study found out that majority of the orphaned girl-students (80.5\%) attended mixed day secondary schools. The study found out that only a meager $19.5 \%$ were learning in boarding schools. Ames(2004) and Yambo (2012)suggests that schooling systems in low performing schools, where the institutional and management challenges are significant, often have poor quality provisions such as high teacher absenteeism, lack of incentives to performance, lack of facilities and resources, low number of female teachers, gender violence, and corporal punishment. Therefore, low quality provisions and low learning outcomes in such schools could lead to girls dropping out of schools. Hunt (2007) supports these findings by stating that high cost of schooling is a central reason for orphaned girls' choice of low quality schools. This indicated that majority of the orphaned girl-students faced a lot of difficulties on their way to and from school. This is in agreement with UNICEF (2004) which states that orphaned girls in mixed day secondary schools face difficulties in accessing and being retained in such schools in rural areas. These difficulties include harassment by boys, long distances to be covered between school and home, early pregnancy, lack of resources and lack of female teachers in secondary schools in the rural areas to act as role models for girls.

The study also considered whether the respondents were day scholars because status of the school affects the survival of the orphaned girl-child in secondary school due to the fees and other levies required in those schools. Besides, there were also distances to be covered, molestation on the way to and from school, and the quality of education at some of the day schools. The study observed that about $80.5 \%$ of the respondents were day scholars. Only about $19.5 \%$ of them were boarders, possibly because a few of the secondary schools offered boarding facilities. The findings on this area indicated that majority of the orphaned girlchildren walked long distances to school, and this was likely to curtail their interests in school 
and learning; thus leading to drop out from school. These findings agree with Tawanda and Gordon (2004) who postulate that long distances to school, are a barrier to children, especially girls' education. They further claim that many of such girls resort to rent for lodgings away from home in order to continue with school. When they are unable to pay rent some girls are forced to find ways of raising money and may be absent from school or arrive at school late and leave early. UNICEF (1999) indicates that in some cases, some of such girls resort to sex for payment in order to raise money to cover for their accommodation costs. The result of such a relationship may be pregnancy; whereby one involved in it may drop out of school.

\section{Number and Gender of Teachers in Guidance and Counseling Department}

The number and gender of teachers in the guidance and counseling department was considered because they are indicators of the department's strength and determination in effectively and efficiently offering the guidance and counseling services to the students.

\section{Table 3}

Effects of the Number of Teachers in Guidance and Counseling Department on the Orphaned Girl - Child's Access and Retention in Secondary School Education

\begin{tabular}{cll}
\hline Number of teachers & Frequency & Percent \\
\hline $0-2$ & 33 & 91.4 \\
$2-4$ & 2 & 5.7 \\
Not applicable & 1 & 2.9 \\
Total & $\mathbf{3 6}$ & $\mathbf{1 0 0 . 0}$ \\
\hline
\end{tabular}

$\mathrm{N}=36$

The study found out that majority of the schools (91.4\%) had the number of teacher counselors ranging from zero to two $(0-2)$. This was likely indicating that in some schools there were no teachers in the department. According to Makame and McGregor (2002) orphans are strongly stigmatized and suffer from grief and psychological problems. A Lack of teacher in the department means more problems to the orphaned girl-child. It is therefore essential to provide orphans with guidance and counseling services which would enable them to adjust to school life and thus retained in secondary school as well as improve in their academic performance. Lack of teacher counselors would encourage poor retention of such orphans in schools, leading to low enrolment of orphaned girl-child in secondary schools.

The gender of teachers in guidance and counseling department was also considered because each gender had a role to play in influencing student's social and educational support hence student's access and retention in secondary school education. The study found out that the majority of schools (72.2) had both male and female counselors in the guidance and counseling department. However, $22.2 \%$ and $5.6 \%$ schools had only male and female counselors in guidance and counseling department respectively. Considering the percentage $(5.6 \%)$ of the female counselors, it showed that more female counselors who could act as role models to the orphaned girls were still needed in these secondary schools. UNICEF (2004) identified lack of female teachers in secondary schools in the rural areas to act as role models to girls as one of the difficulties girls face in accessing and being retained in schools. This is 
DEVELOPMENT

Vol. 1 , No. 4, 2012, E-ISSN: $2226-6348$ @ 2012 HRMARS

because the facilities for the accommodation and security of such teachers were usually absent and inadequate in rural areas.

Poor Academic Performance as a Cause of Orphaned Girl - Child's Dropout

Poor academic performance as a cause of orphaned girl - child's drop out from school was considered in the study because academic performance influences and motivates the access and retention of an individual in an institution of learning. Poor academic performance demoralizes and discourages an individual learner. Low quality provision of resources necessary in educational facilities is evidenced in the rural areas, whereby low achievement results in repetition of a class, lack of self esteem and hence dropout from school.

\section{Table 4}

Effects of Poor Academic Performance on the Orphaned Girl - Child's Access and Retention in Secondary School Education

\begin{tabular}{lll}
\hline Response & Frequency & Percentage \\
\hline Very high & 6 & 16.7 \\
High & 22 & 61.1 \\
Low & 5 & 13.9 \\
Very low & 2 & 5.6 \\
Never & 1 & 2.7 \\
Total & $\mathbf{3 6}$ & $\mathbf{1 0 0 . 0}$ \\
\hline
\end{tabular}

$\mathrm{N}=36$

The result showed that poor academic performance highly causes orphaned girl child's drop out from school. Table 8 showed that poor academic performance was rated high (61.1\%) and very high (16.7\%). According to Bandura (1986) the more a student is motivated the more a student builds self - esteem and achieve academically. Lack of motivation results into many orphaned girl -children who are demoralized performing poorly and thus dropping out of school to work at home in the family farm in order to fend for themselves and their siblings (Case, Paxon and Ableidinger, 2004). In developing countries, proponents of class retention on academic performance hold that students who fail to reach the minimum standard set for a given class is to spend more time in the same class (Hunter \& May, 2003). This means that such orphaned girl-children are forced to repeat a class. The repetition of a class highly edge many students out of school especially orphaned girl - child. This is because many teachers feel that promoting poor academic achievers automatically would not enable them to understand and assimilate the curriculum as they reach higher classes. However, Ngau (1991) argues that repetition of a class does not improve the academic achievement of students who are poor academically. Instead, it hurts their feelings, self image and their prospects of future success. Furthermore, low academic achievers have negative self - concept that can results into their leaving school; so this could be possible with the orphaned girl - child. The study further observed that sporadic cases of repetition in form one up to form four could lead to drop out from school .Al Sammarai and Peasgood (1998) also observed that orphaned girl children who had repeated a class were more likely than non repeaters to drop out from school. This was because of low achievement and girls becoming over-age after having taken 
long in one class due to repetition. Pentiman (1999) notes that as a girl child grows older, the opportunity cost of her time often increases, leading to her dropout. The low achievement of such orphans is also related to absenteeism which may results into drop out from school. This was not an exception to the orphaned-girl child in the area of study

Distance of the Students' Closest Mixed Day Secondary School

The approximate distance of the closest mixed day secondary school from the students' home was considered in the study because students wake up very early to go to school and by the time they arrive at school, they are hungry and tired and this affects their academic concentration and performance.

\section{Table 5}

Effects of the Distance the Orphaned Girl- Child Covers from Home to the Closest Mixed Day Secondary School on Her Access and Retention in Secondary School Education

\begin{tabular}{lll}
\hline Distance & Frequency & Percent \\
\hline $0-2 \mathrm{~km}$ & 145 & 31.2 \\
$3-4 \mathrm{~km}$ & 110 & 23.7 \\
$5-6 \mathrm{~km}$ & 94 & 20.13 \\
$7-8 \mathrm{~km}$ & 57 & 12.1 \\
Over $8 \mathrm{~km}$ & 60 & 12.7 \\
Total & $\mathbf{4 6 8}$ & $\mathbf{1 0 0 . 0}$ \\
\hline
\end{tabular}

$\mathrm{N}=468$

The study observed that about $54.9 \%$ of the orphaned girl-students cover a distance of four kilometers $(4 \mathrm{~km})$ and below to reach the closest day mixed secondary schools. However, $45.1 \%$ of them had to traverse a distance of $5 \mathrm{~km}$ and above to reach their schools. This means that such orphaned girls take a long time to reach school and get back home from school, and this consequently affects their academic concentration and performance. Tawanda and Gordon (2004) postulate that high school orphaned girls have no opportunity to do homework both at school and home because of the distance and heavy domestic chores after school. They further state that as a coping mechanism some of them have sought lodgings away from home in order to continue with schooling. Such lodgings away from home place them at risk of abuse from men who know that they live alone without parental protection.

Furthermore, the time taken by an orphaned girl- child to get back home from school and the long distance covered between home and school were found to have negative effect on the survival of the orphaned girl-child in secondary school. Some children walked more kilometers to school, that was why about $18.7 \%$ reached home after 7.00 p.m. According to UNICEF (2001) long distance to school is a barrier to children's education, especially girls. Children wake up very early to school and by the time they arrive there they are hungry and tired and this affects their concentration and performance. They also take long to get back home from school and consequently have no opportunity to do their homework, especially with an orphaned girl - child who has to bear with domestic chores after school (Tawanda and Gordon, 2004; Yambo 2012). 
DEVELOPMENT

Vol. 1 , No. 4, 2012, E-ISSN: $2226-6348$ @ 2012 HRMARS

Other Causes of Orphaned School Girls' Dropout from School

The other causes (in the table below) of orphaned school girls' dropout from school were considered in the study because there were indications that the survival of orphaned girlchildren in secondary school education happened to be an issue requiring research.

Table 6

Other causes for Orphaned Girls' dropout from school and their effects on orphaned girlchild's access and retention in secondary school education

\begin{tabular}{|c|c|c|c|c|c|c|}
\hline & Yes & & No & & Tota & \\
\hline Causes & Frequency & Percentage & Frequency & Percents & $\mathbf{N}$ & $\%$ \\
\hline Lack of fees & 381 & 81.4 & 87 & 18.6 & 468 & 100 \\
\hline Pregnancy & 334 & 71.3 & 134 & 28.7 & 468 & 100 \\
\hline Marriage & 169 & 36.2 & 299 & 63.8 & 468 & 100 \\
\hline Forced repetition & 261 & 55.8 & 207 & 44.2 & 468 & 100 \\
\hline Employment & 76 & 16.3 & 392 & 83.7 & 468 & 100 \\
\hline Forced transfer & 140 & 39.9 & 328 & 60.1 & 468 & 100 \\
\hline Poor health & 168 & 35.9 & 300 & 64.1 & 468 & 100 \\
\hline Initiation rites & 25 & 5.4 & 443 & 94.6 & 468 & 100 \\
\hline Molestation & 374 & 78.8 & 94 & 21.2 & 468 & 100 \\
\hline Lack of books & 180 & 38.8 & 268 & 61.2 & 468 & 100 \\
\hline \multicolumn{7}{|l|}{ Lack of } \\
\hline encouragement & 363 & 77.4 & 105 & 22.6 & 468 & 100 \\
\hline
\end{tabular}

In each reason $\mathrm{N}=468$

The study observed that majority of orphaned girl-children dropout of school due to lack of fees (81.4\%) and pregnancy (71.3\%). Other causes include repetition of a class (55.8\%) forced transfer (39.9\%), employment (16.3\%) and poor health (35.9\%). These causes were also identified by Batbaatar et al (2006) as difficulties that girls face in accessing and being retained in secondary school education, especially in rural areas. Molestation of school girls on the way to and from school was also considered in the study because it is perceived that girlchildren are far more vulnerable to molestation and sexual abuse both in the community and school leading to dropout from school. The study found out that $78.8 \%$ of the orphaned girlchildren indicated that they were molested on their way to and from school. Only $21.2 \%$ indicate that they were not molested. These findings were in consistent with UNICEF (2004) which identified this as one of the difficulties girls face in accessing and being retained in secondary schools in rural areas. Other difficulties include harassment by boys, long distance to and from schools, and threats of being raped. This showed that there was little security given to girls between home and school. This was also postulated by Castle (1996) who noted that out of class issues such as sexual abuse and rape edged girls out of school; whereby an orphaned girl-child may be a victim.

The study also observed that $61.2 \%$ of the parent/guardians do not buy books needed in school, though $77.4 \%$ of them encourage the orphaned girl-child to go to school. However, Tawanda and Gordon (2004) indicate that the major barrier of orphaned girl-child to access and be retained in secondary school education is lack of money for uniforms, books, pens and 
other costs associated with schooling. Whilst most of the children are anxious about their parent/guardians ability to afford the money for the above items, sometimes they are provided with these items in school.

Hypothesis Test on School Related Effects of Orphan hood on the Girl- Child's Access and Retention in Secondary School Education

This section presents more findings from the analysis of data to test the hypothesis below: Hypothesis1: There is no statistically significant school related effects of orphan hood on the girl-child's access and retention in secondary school education.

The hypothesis testing on school related effects of orphan hood on the girl-child's access and retention in secondary school education used a chi- square test to analyze the data based on alpha 0.05 level of significance. One of the school related data tested included the effect of orphaned girl-child's forced repetition of a class and its influence in her access and retention in secondary school education. Table 11 presents the results of the chi-square test.

Table 6

The Hypothesis Test on School Related Effects of Orphan hood on the Girl-Child's Access and Retention in Secondary School Education

\begin{tabular}{llll}
\hline & Value & Df & Assymp. Sig \\
\hline Computed chi-square & 17.857 & 1 & .000 \\
Critical chi-square & 3.841 & 1 & .050 \\
\hline
\end{tabular}

$\mathrm{P}<0.05$ chi-square $=17.857^{*}, \mathrm{df}=1, \quad \mathrm{~N}=36, \quad \mathrm{P}=.000$

The result showed that most of the school related effects had statistically significant influence on an orphaned girl-child's access and retention in secondary school education, alpha 0.05 $(P<0.05)$. From the result, the hypothesis is rejected. This was because in table 11 above the computed value of the chi-square is greater than the critical value of the chi-square. According to Mangal (2004), when the computed value of chi-square is greater than, or equal to the critical value of chi-square, then it is significant and consequently the null hypothesis is rejected. However, when the computed value of the chi-square is less than the critical value of the chi-square, then it is non-significant and consequently the null hypothesis is not rejected. For instance, Table 10 indicates that forced repetition of a class, as one of the school related factors, is one of the major causes $(55.8 \%)$ of the orphaned girl-child's dropout from school. In this case, it may be concluded that most of the school related effects discourage a student from continuing with education and such a student can easily drop out from school. This finding is in congruent with Hunter and May (2003) who hold that students who fail to reach the minimum standards set for a given class spends more time in the same class, and this is a deterrent to retention in school education. Therefore, many of such orphaned girlchildren get hurt; lose their self-image and prospects for future success.

\section{Conclusion}

This study made the following conclusion based on findings:

The study showed that several school related factors affect an orphaned girl-child's access and retention in secondary school education. These factors include: category of school, 
professional qualification of the teachers, efficiency of guidance and counseling department in schools as well as forced repetition, among others. The data gathered from respondents who participated from the research revealed that there were significant school related effects of orphanhood on the girl-child's access and retention in secondary school education. This was found out to occur in the form of overburdening domestic chores for orphaned girls after school, peer pressure, lack of motivation due to poor academic performance, lack of qualified counselors, especially female counselors to act as role models, forced repetition and distance of school from home among others.

\section{Recommendations}

The study thus, had the following recommendation:

Since there were significant school related effects of orphanhood on girl-child's access and retention in secondary school education, the ministry of education should offer guidance and counseling interventions in schools in order to enable all the schools stakeholders to deal with issues that affect the orphaned girl-child's access and retention in secondary school education. More teacher counselors needed to be trained, especially the females, and deployed to schools. The findings from this study, therefore, showed that there was a need for certain structures put in place to counteract the school related effects on orphaned girlchild in order to enable her to access and be retained in secondary school education.

\section{References}

Admassie, A. (2003). Child Labour and Schooling in the Context $f$ a Subsistence rural economy: Can they be compatible? International Journal of Educational Development, 23(2):167-185.

Ainsworth, M., Beegle, K., \& Koda, G. (2005). The Impact of Adult Mortality and Parental deaths on primary schooling in North-West Tanzania. The Journal of Development Studies, 41(3):412-439.

Ainsworth, M., \& Filmer, D. (2006). Inequality in children's schooling: AIDS, Orphanhood, Poverty and Gender. World Development 34 (6): 1099 - 1128.

Al Sammarai, S., \& Peasgood, T. (1998). Educational Attainments and Household Characteristics in Tanzania. Economics of Review, 17(4): 395-417.

Ames, P. (2004) Schooling for Girls in Rural Peru. Id21 (internet). Available from ext/insightseduzart7.html

Ballian, E. S. (1988). How to design, Analyze and write doctoral or master Research. (2 ${ }^{\text {nd }}$ Edition) Canhan MD; University Press of America INC.

Bandura, A. (1986) Social Cognitive Theory in Cultural Context. Applied Psychology: An International Review pg 269-290.

Barton, T., \& Wamai, G. (1994). Equity and vulnerability: A situational analysis of woman adolescents and children in Uganda, Kampala: Uganda National Council for children.

Batbaatar, M., Bold, T., Marshall, J., Oyuntsetseg, D., Tamir, C., \& Tumennast, G. (2006) Children on the Move: rural urban migration and access to education in Mongolia. CHIP Report No. 17. Save the Children UK/CHIP.

Bhargava, A., Bigombe, B. (2003). Public Policies and the orphans of AIDS in Africa. BMJ 326 (7403): 1387 - 1389 [PubMed].

Berc. (1995). Basic Education forum. Volume 6. Development and Communication Support. Nairobi. 
Borg, W. R., \& Gall, M. E. (2003). Educational Research: An introduction. New York: Longman INC.

Boyle, S., Brock, A., Mace, J., \& Sibbons, M. (2002). Reaching the Poor: The Cost of Sending Children to School. Synthesis Report. London: DFID.

Brock, C., \& Cammish, N. (1997) Factors Affecting Female Participation in Education in Seven Developing Countries. Education Research Paper No. 9. London:DFID.

Case, A., Paxson, C., \& Ableidinger, J. (2004). Orphans in Africa: Parental health, poverty and school Enrolment. Demography, 41:3, PP. 483 - 508.

Case, A., \& Ardington, C. (2004). The Impact of Parental Death on School Enrolment and Achievement: Longitudinal evidence from South Africa. Cape Town: University of Cape Town

Casely, J. D., \& Kumar, K. (1988). The collection, Analysis, and use of monitoring and evaluation Data. A World Bank publication. Washington D.C. USA.

Castle, E. B. (1966), Growing Up in East Africa. Oxford University Press. Ibadan.

Corcoran, C. (1995) - Rags to Rags; Poverty and mobility in the United States. Annual Review of Sociology, 21, 237- 267.

Crampin, A., Floyd, S., Glynn, J., Madise, N., Nyondo, A. M. K. (2003). The long term effect of orphanhood on the motility and physical wellbeing of children in Malawi. 17 (3): $389-$ 97.

Cronbach, J. (1951). Coefficient Alpha and the intended Structure of Tests. Psychometrics 16(297-334)

Dachi, H. A., \& Garrett, R. M. (2003) Child Labour and its impact on Children's Access to, and Participation in Primary Education:A case Study from Tanzania. London: DFID.

Deininger, K., Garcia, M., \& Subbarao, K. (2003). AIDS - Induced orphanhood as a systematic shock: Magnitude, impact, and programme interventions in Africa. World Development, 31, (7), $1201-1220$.

Drew, R. S., Makufa, C., \& Foster, G. (1998). Strategies for providing care and support to children orphaned by AIDS. AIDS care (10), 9-16.

Duncan, G. J., Young, W. J., Brooks - Gunn, J., \& Smith, J. R. (1998). How much does childhood poverty affect the life chances of children? American sociological Review, 63 (3), 406 423.

Ersado, L. (2005). Child Labour and Schooling decisions in urban and rural areas: Comparative Evidence from Napal, Peru, and Zimbabwe. World Development, 33(3): 455-480.

Fentiman, A., Hall, A., \& Bundy, D. (1998) School Enrolment Patterns in Ghana: A comparative Study of the Impact of location, gender, age, and health on Children's Access to Basic Schooling. Comparative Education, 35(3):331-349.

Forum for African Women Empowerment. (1994). Girls in Domestic Activities within Their Homes, Expert paper prepared for the Experts Meeting on elimination of all forms of discrimination against the girlchild. Inocenti Research Centre, Florence, Italy.

Fraenkel, J. R., \& Wallen, W. E. (2000). How to design and Evaluate in Education (4 ${ }^{\text {th }}$ Edition) Library of Congress: MC. Graw - Hill INC.

Glick, P., \& Sahn, D. E. (2000) Schooling of Boys and Girls in West African country: The Effects of Parental Education, Income and Household structures. Economics of Education Review,19:63-87.

Government of Kenya. (2001), Education For All (EFA) in Kenya: A National Handbook on EFA 2000 and Beyond. Government Printer, Nairobi. 
Guarcello, L., Lyon, S., \& Rosati, F. (2004) Orphanhood and Child Vulnerability: Burundi. Understanding Children's Work Project.

Guo, G., \& Harris, K. M. (2000). The mechanisms mediating the effects of poverty on children's intellectual development. Demography, 37 (4), 431- 447.

Gutierres, L. (1990). Working with women of colour: An empowerment perspective Social work. 35, $149-153$

Hargreaves, J. R., \& Glynn, J. R. (2002). Education Attainment HIV - 1 infection in developing countries. A systematic review. Tropical Medicine and International Health. 7 (6) $489-$ 98.

Hill, M. S., \& Dancun, G. J. (1987). Parental family income and the socio-economic attainment of children. Socio Science Research, 6, $39-73$.

Hill, M. S., \& Sandfort, J. R. (1995). Effect of childhood poverty on productivity later in life implication for public policy. Children and Youth Service Review. 17( 1/2) $91-126$.

Hunt, F. (2007) Schooling Citizens: A Study of Policy in Practice in South Africa. Unpublished Dphil Thesis. Brighton: University of Sussex.

Hunter, N., \& May, J. (2003) Poverty Shocks and School Disruption Episodes among Adolescents in South Africa. CSDS Working Paper, No. 35.

Kadzamira, E., \& Schiwana, P. (2000). Can free primary education meet the needs of the poor? Evidence from Malawi. International Journal of Educational Development,23.

Kathuri, N., \& Pals, A. (1993). Introduction of Education Research. Egerton University Njoro Kenya. Education Media Centre.

Konate, M. K., Gueye, M., \& Vita, N. T. (2003) Enrolment in Mali: Types of Household and How to Keep Children at School. Paris: UNESCO.

Levy, S. R., Lampman, C., Handle, A., Flay, B. R., \& Weeks, K. (1993). Young adolescents' attitudes towards sex and substance abuse: Implication for AIDS prevention. AIDS education and prevention, 5, $340-351$.

Lindblade, K. F., Odhiambo, D., Rosen, K., \& Decock, K. (2003). Health and Nutritional Status of Orphans $<6$ years old cared for by relatives in Western Kenya. Tropical Medicine and International Health. 8(1): $67-72$.

Makame, V., Ani, C., \& Grantham -McGregor, S. (2002) Psychological wellbeing of orphans in Dar-es-Salaam, Tanzania, Acta Paediatr. 91(4): 459-65 [PubMed]

Mangal, S. K. (2004) Statistics in Psychology and Education, Prentice-Hall of India. New Delhi. Second Edition.

Meier, E. (2003). The growth of AIDS orphans and policy solutions.Pediatric Nursing, 26(1),75-77.

Moore, A. Beverly S., Schreiner, M., Sherraden, M., Lombe, M., Cho, E., Johnson, L., and Vonderlack, R. (2001). American dream policy demonstration: A National Demonstration of individual Development Accounts. Washington University in St. Louis, George Warren Brown School of Social Works, Centre for Social Development.

Mugenda, O. M., \& Mugenda A. G. (1999). Research methods - quantitative and qualitative approaches. Nairobi - Kenya. Africa Centre for Technology Studies (ACTS).

Orodho, A. J. (2004). Essential of educational and Social Sciences. Research Methods. Masola Publisher.

Ngau, M. M. (1991), Grade Retention and School Dropouts in Kenyan Primary Schools: A Critical Analysis of Access and Equity Issues in Education. University of Califonia, Los Angeles. 
Paikoff, R. L. (1995). Early Heterosexual debut: situations of sexual possibility during the transition to adolescence. America Journal of Orthopsychiatry, 65 (3), $389-401$.

Phillips, M., \& Pearson, V. (1996). Coping in Chinese Communities: The need for a new research agenda. In:Bond M., editor. Chinese Psychology. Hong Kong: Oxford University Press.

Rono, K. J. (1990). Factors influencing the rate of dropouts among the Secondary school Students in Nandi District in Kenya. Un-published M. Ed. Thesis Nairobi University.

Sherraden, M. (1990, 1991). Assets and the poor: A new American welfare policy, New York: M.E. Sharpe.

Sherraden, M. (1986). School dropouts in perspective Education Forum. 51, (1). 15 - 31.

Slonim - Nevo, V., Auslander, W. F., \& Ozawa, M. N. (1995). Educational Options and AIDS related behaviours among troubled adolescents. Journal of pediatric psychology, 20: 41-60.

Silver, H. (1973) social progress and educational wastage equal opportunities in education, Methuen and Co. Ltd. London.

Ssewamala, F., \& Culy, J. (2005). Increasing Life Chances for Orphaned children in Africa. Testing an Asset - Based development strategy. Washington University.

Steinberg, L., Darling, N., \& Fletcher, A. C. (1989). Authoritative Parenting and Adolescent Adjustment. An Ecological Journey. In Moen, P., Elder, Jr. and Lascher, K. (eds). Experiencing lives in context: Perspective in the Ecology of Human Development. Washington DC: Library Congress.

Stiffman, A. R., Dore, P., Cunninggham, R., \& Earls, F. (1995). Person and environment in HIV risk behaviour change between adolescence and young adulthood. Health Education \& Behaviour, 27 (6). $708-724$.

Tawanda, R., \& Gordon. (2004). Comprehensive review of gender issues in education sector. A report presented for UNICEF/MOSESC, 49 (1): 38-40.

UNESCO. (2007) EFA Global Monitoring Report 2007: Strong Foundations, Early Childhood Care and Education. Paris: UNESCO Publishing.

United Nations Programs on HIV/AIDS (UNAIDS). (2004). Bijing:China Ministry of Health;2004. A joint assessment of HIV/AIDS prevention, treatment and care in China. Available at joint assessment 2004 ea pdf. pdf.

United States Agency International Development (USAID). (2004). Africans Orphaned Generations. New York: Usaid.

United Nations Children Educational Fund (UNICEF). (1999). Zimbabwe 1999 National Child Labour Country Report.

United Nations Children Educational Fund (UNICEF). (2001). A Situational Analysis of Orphans and Vulnerable Children and Adolescent in Zimbabwe: Summary Report 2001.

United Nations Children Educational Fund (UNICEF). (2004 a) Information by country. Retrieved on Monday $11^{\text {th }}$, from www.Unicef.Org

United Nations Children Educational Fund (UNICEF). (2004 b). Innovations and Lessons learned in 2003. New York: Unicef.

Urrassa, M., Boerma, J. T., Ng'weshemi, J. Z. L., Isingo, R., Schapink, D., \& Kumogola, Y. (1997). Orphanhood, child fostering and the AIDS Epidemic in Rural Tanzania. Health Transition Review 7 (supp. 2): $141-153$.

Wamahiu, M. (1991). Cash crisis looms on top schools waiting for grant funds for 1991. Daily Nation $10^{\text {th }}$ May. 
Wang, Y. (2003). Call for urgent action to help children and orphans in China. Beijing: Aizhixin Institute of Health Education. Pp 29-34.

Weerdt, J. D. (2006). Kagera Health and Development Survey, Basic Information Documents; Mimeo. World Bank, Washington DC.

World Bank. (2001). Helping the children: World Bank Directory of HIV/AIDS. Interventions in Africa. Washington, DC: World Bank.

Yadama, G., \& Sherraden, M. (1996). Effects of Assets on Attitudes and Behaviours: Advance of a social policy proposal. Social Work Research 20 (1): 3- 11.

Yambo, J. M. O. (2012). Determinants of KCSE Examination Performance in SDA Sponsored Schools: A Key to Academic Promotion to the next Level of Learning. Lambert Academic Publishing. Saarbrucken, Germany

Yambo, J. M. O., Kindiki, J. N., \& Tuitoek, J. K. F. (2012). Investigating High School Principals' Stress in Relation to their Job experience in Schools in Southern Nyanza Region of Kenya. International journal of Academic Research in Progressive education and Development 4(1):44-63

Zhan, M., \& Sherraden, M. (2003). Assets, expectations and children's Educational Achievement in Female - Headed Households. Social Services Review (June): 191 - 211. 